\title{
Study of maternal and fetal outcome in elective and emergency caesarean section
}

\author{
Thakur $\mathrm{V}^{1}$ Chiheriya $\mathrm{H}^{2}$ Thakur $\mathrm{A}^{3}$ Mourya $\mathrm{S}^{4}$ \\ ${ }^{1}$ Dr Vibhuti Thakur, Senior Resident, Department of Obstetrics \& Gynecology, MGMMC \& MY Hospital, Indore, MP, \\ ${ }^{2}$ Dr Heena Chiheriya, Senior Resident, Department of Obstetrics \& Gynecology, GMERSMC Sola, Ahmadabad, Gujarat, \\ ${ }^{3}$ Dr Ashok Kumar Thakur, Assistant Professor, Department of Medicine, MGMMC \& MY Hospital, Indore, MP, ${ }^{4}$ Dr \\ Sudhir Mourya, Professor, Department of Medicine, Index MC \& RC Indore, MP, India.
}

Address for correspondence: Dr Vibhuti Thakur, Email: drvibhuti01 @ gmail.com

\begin{abstract}
Introduction: Caesarean section is one of the most performed surgical procedures all over the world. The present study was conducted to determine the maternal \& neonatal outcome and complications in two groups of pregnancy among women with elective and emergency cesarean section. So that measures can be taken to reduce morbidity and mortality in near future. Material \& Methods: A prospective observational study carried out in department of Obstetrics and Gynecology, M.G.M Medical College and M.Y. Hospital ,Indore (M.P). All patients who underwent caesarean section are divided into two groups as per the timing of procedure in emergency or electively. The two groups were compared on the basis of age, parity, indication, booking status, intra operative \& post op complications, and maternal \& fetal outcome. Results: The incidence of caesarean section was $30.25 \%$. The proportion of elective and emergency caesarean was $21.63 \%$ and $78.37 \%$ respectively. All of the complications were significantly higher in emergency group in terms of both maternal and fetal outcome. Conclusion: The incidence of caesarean section is high in MGM medical college Indore and the overall complication rate is higher in emergency caesarean than elective caesarean section group.
\end{abstract}

Keywords: Caesarean Section, Maternal and Fetal Outcome.

\section{Introduction}

Caesarean delivery is defined as birth of viable fetus through incision in abdominal wall (laprotomy) and uterine wall (hysterotomy) [1]. Caesarean section is a lifesaving procedure that is firmly ensconced in obstetric practice. Today, it is one of themost commonly performed surgical procedures; but unfortunately caesarean sections are associated with agreat deal of maternal morbidity. Before the availability of wide spectrum antibiotics, blood transfusion facilities and good anesthetic techniques, caesarean section was used only to save the life of the mother and was met with the mortality of $50-70 \%$. With the immense advances in anesthetic services and improved surgical techniques, the morbidity and mortality of this procedure has come down considerably. In a previous study it was found that

Manuscript received: $27^{\text {th }}$ Oct 2015

Reviewed: $4^{\text {th }}$ Nov 2015

Author Corrected: $20^{\text {th }}$ Nov 2015

Accepted for Publication: $9^{\text {th }}$ Dec 2015 maternal mortality due to caesarean delivery was 2.2 per 1,000,000 in the United States [2]. Elective caesarean is a term used when the procedure is done at a pre-arranged time during pregnancy to ensure the best quality of obstetrics, anesthesia, neonatal resuscitation and nursing services. The procedure is termed as emergency caesarean section when it is performed due to unforeseen or acute obstetric emergencies [3]. It is seen that morbidity and mortality are associated more with emergency procedures than with elective procedures [4].

This alarming rise in the rate of cesarean sections has been a matter of concern to the profession and the public and the need to scrutinize existing practices has been voiced very often. With this background the study was conducted to Study maternal morbidity of elective and emergency caesarean sections in a tertiary care teaching hospital.

\section{Material and Method}


The present study was a prospective observational study carried out in department of Obstetrics and Gynecology, M.G.M Medical College and M.Y.Hospital ,Indore(M.P). All patients who underwent caesarean section are divided into two groups as per the timing of procedure in emergency or electively. The two groups were compared on the basis of age, parity, indication, booking status, intra operative \& post op complications, and maternal \& fetal outcome.

Study Period: October 2013-October 2014.

Study Subject: All the Caesarean sections emergency or elective from October 2013 - October 2014 irrespective of indications, age, maternal and fetal outcome.

Inclusion criteria: All lower segment caesarean sections performed at the hospital during the one year period were included.

Exclusion criteria- Classical caesarean sections were excluded.

Emergency cesarean section was defined as the one performed as soon as possible after the decision of operation was made without prior pre-operative preparation.
Elective cesarean was defined as the one performed after proper planning and preoperative preparations.

Collection of data- The patients were divided into those undergoing elective caesarean section and those undergoing emergency caesarean section. Detailed history and examination was done and the indications for caesarean section, the preoperative findings and complications noted in detail with the help of a proforma. Information regarding post-operative morbidity was also collected. Consent from the subject was obtained, prior to collection of any data No interventions were made in this study. The outcomes studied were-Incidence of elective and emergency caesarean sections, indications, age distribution, gravida, antenatal complications, intra-operative and post- operative complications. Duration of hospital stay of more than 6 days was considered as an indicator for post-operative morbidity.

Statistical Analysis- Descriptive statistics such as mean, standard deviation and percentage were used and to find association chi square test was used.

Statistical software: The statistical software SPSS 20.0 was used for the analysis of the data and Microsoft word and excel have been used to generate graphs, tables etc.

\section{Results}

Total number of admissions during the study period: 13925.Total number of labor during the study period: 10634

Total number of cesarean sections during the study Period: 3217 . Incidence of cesarean section: $30.25 \%$

Table No. 1: Distribution of Patients According to Type of Caesarean Section

\begin{tabular}{|l|l|l|}
\hline Type of Caesarean Section & No. & \% \\
\hline Elective & 696 & 21.63 \\
\hline Emergency & 2521 & 78.37 \\
\hline Total & $\mathbf{3 2 1 7}$ & $\mathbf{1 0 0 . 0 0}$ \\
\hline
\end{tabular}

In the present study, 3217 caesarean sections studied in which $78.37 \%$ of cesarean sections were emergency, while $21.63 \%$ cases were elective cesarean sections.

Table No. 2: Distribution of Patients According to Age Group

\begin{tabular}{|l|l|l|l|l|}
\hline Age Group & Elective Group & & Emergency Group \\
\hline & $(\mathbf{N = 6 9 6 )}$ & $\mathbf{N}=\mathbf{2 5 2 1})$ & \\
\hline & No. & $\mathbf{\%}$ & No. & \% \\
\hline 18-25 years & 362 & 52.01 & 1466 & $58.15 \%$ \\
\hline 26-30 years & 321 & 46.12 & 903 & 35.81 \\
\hline $30-45$ years & 13 & 1.86 & 152 & 6.03 \\
\hline Total & 696 & 100.00 & 2521 & 100.00 \\
\hline
\end{tabular}


Chi-square $=37.2$, Degrees of freedom $=2$, Probability $<0.01$

The above table showed, patients were selected from 18-45 years of age, majority of patients being in 18-25 years elective $(52.01 \%)$ and emergency $(58.15 \%)$ while in $26-30$ years elective were $46.12 \%$ and emergency in $35.81 \%$ whereas only $1.86 \%$ cases in elective and $6.03 \%$ cases as emergency in $30-45$ years age group. The association between age and type of caesarean was significant with $\mathrm{P}$ value $<0.01$.

Table -3: Distribution of Patients According to Indication for Cesarean Section

\begin{tabular}{|c|c|c|c|c|}
\hline \multirow[t]{3}{*}{ Indication } & \multicolumn{2}{|c|}{ Elective Group } & \multicolumn{2}{|c|}{ Emergency Group } \\
\hline & $(\mathrm{N}=696)$ & & $(\mathrm{N}=2521)$ & \\
\hline & No. & $\%$ & No. & $\%$ \\
\hline Previous LSCS & 549 & 78.87 & 1171 & 46.44 \\
\hline Breech & 78 & 11.21 & 209 & 8.29 \\
\hline Oligohydramnios & 56 & 8.05 & 273 & 10.83 \\
\hline Placenta previa & 4 & 0.57 & 66 & 2.62 \\
\hline Wants cesarean section & 4 & 0.57 & - & - \\
\hline For primary infertility & 11 & 1.58 & 13 & 0.52 \\
\hline Transverse lie & 3 & 0.43 & 43 & 1.71 \\
\hline $\begin{array}{l}\text { Meconium } \\
\text { stained }\end{array}$ & - & - & 298 & 11.82 \\
\hline \multicolumn{5}{|l|}{ liquor } \\
\hline Cephalopelvic & - & - & 183 & 7.26 \\
\hline \multicolumn{5}{|l|}{ disproportion } \\
\hline Non progress of labor & - & - & 154 & 6.11 \\
\hline Abruptio placentae & - & - & 59 & 2.34 \\
\hline Failed induction & - & - & 146 & 5.79 \\
\hline $\begin{array}{l}\text { Premature } \\
\text { rupture of }\end{array}$ & - & - & 94 & 3.73 \\
\hline \multicolumn{5}{|l|}{ membrane } \\
\hline Eclampsia & - & - & 37 & 1.47 \\
\hline
\end{tabular}

In above study, it seems that caesarean section in emergency group (2521) was more than elective group(696) and the most common indication was previous LSCS in both the group,76.87\% in elective and $46.44 \%$ in emergency group, followed by breech, oligohydromnios, placenta previa, wants cesarean section, for primary infertity, transverse lie, in both group respectively and meconium stained liquor, cephalopelvic disproportion, Non progress of labour, abruption placentae, failed induction respectively in only emergency group.

\section{Discussion}

During our study period there were 10634 total deliveries, of which 3217 were Caesarean deliveries. Cesarean delivery rate in our hospital is $30.25 \%$. Elective caesarean was $21.63 \%$ and emergency Caesarean were $78.37 \%$.

In our study period there were 11 maternal mortalities out of 3217 caesarean sections. All mortalities were in emergency group.

Total number of maternal mortality: 11 Percentage of maternal mortality in Emergency group: $11 / 2521 * 100=0.44 \%$ Percentage of maternal mortality in total cesarean sections: $11 / 3217 * 100=0.34 \%$. During the last decades there has been 2-3 fold raises in incidence from the initial rate of about $10 \%$. This is because of the liberalization of its medication and its superiority over difficult vaginal operation. According to WHO cesarean section rate of more than $15 \%$ is not justified.The overall maternal mortality rate is 6-22 deaths per 100000 live births, with approximately $1 / 3$ to $1 / 2$ of maternal death after cesarean delivery directly attributed to a surgical procedure and in part related to conditions that may lead to perform cesarean delivery [5]. 
Elective cesarean section may reduce the incidence of emergency cesarean section that is associated with high maternal morbidity and mortality. After excluding medical disorder and severe antenatal complications, the relative risk for emergency intrapartum compared with elective cesarean section is approximately 1.7:1.0[6].

Table No. 4: Distribution of Patients according to Postoperative Complications

\begin{tabular}{|c|c|c|c|c|c|}
\hline \multirow{3}{*}{$\begin{array}{l}\text { Postoperative } \\
\text { Complications }\end{array}$} & \multirow{2}{*}{\multicolumn{2}{|c|}{$\begin{array}{l}\text { Elective Group } \\
\mathrm{N}-696)\end{array}$}} & \multirow{2}{*}{\multicolumn{2}{|c|}{$\begin{array}{l}\text { Emergency Group } \\
(\mathrm{N}=2521)\end{array}$}} & \multirow[t]{3}{*}{$P$ value } \\
\hline & & & & & \\
\hline & No. & $\%$ & No. & $\%$ & \\
\hline Blood transfusion & 36 & 5.17 & 568 & 22.53 & $\begin{array}{l}\text { chi-square }=108 . \\
\text { Degrees of } \\
\text { freedom }=1 \\
\text { probability }=0.000\end{array}$ \\
\hline Febrile morbidity & 9 & 1.29 & 156 & 6.19 & $\begin{array}{l}\text { chi-square }=26.9 \\
\text { degrees of freedom }=1 \\
\text { probability }=0.000\end{array}$ \\
\hline Urinary tract infection & 17 & 2.44 & 254 & 10.10 & $\begin{array}{l}\text { chi-square }=41.2 \\
\text { degrees of freedom }=1 \\
\text { probability }=0.000\end{array}$ \\
\hline Wound infection & 89 & 12.78 & 671 & 26.62 & $\begin{array}{l}\text { chi-square }=57.8 \\
\text { degrees of freedom }=1 \\
\text { probability }=0.000\end{array}$ \\
\hline
\end{tabular}

\begin{tabular}{|l|l|l|l|l|l|}
\hline Wound gaping & 33 & 4.74 & 164 & 6.51 & $\begin{array}{l}\text { chi-square }=22.6 \\
\text { degrees of freedom }=1 \\
\text { probability }=0.000\end{array}$ \\
\hline Prolonged catheterization & 12 & 1.73 & 171 & 6.78 & $\begin{array}{l}\text { chi-square }=26.0 \\
\text { degrees of freedom }=1 \\
\text { probability }=0.000\end{array}$ \\
\hline Secondary PPH & 4 & 0.57 & 23 & 0.91 & $\begin{array}{l}\text { chi-square }=0.747 \\
\text { degrees of freedom }=1 \\
\text { probability }=0.387\end{array}$ \\
\hline Obstetric hysterectomy & 0 & 0.00 & 1 & 0.04 & $\begin{array}{l}\text { chi-square }=0.277 \\
\text { degrees of freedom }=1 \\
\text { probability }=0.599\end{array}$ \\
\hline
\end{tabular}

When both the groups were compared, the complication percentage in emergency group was much higher as compared to the complications in elective group. And the results were statistically significant.

Majority of patients $(58.15 \%)$ in Emergency cesarean group were younger age group of $18-25 \mathrm{yr}$ as observed by $\mathrm{Al}$ Nuiam et al where in his study younger age group (<25yr) constituted 28.6\% [7]. As observed by Rajesh Kumar (2002)-each pregnancy whether teen or otherwise has to be considered important as maternal complications cannot be predicted. Reasonable and Emergency Obstetric care should be made available to all pregnant women at all times, since child birth can take place at any time and also complication can occur at any time [8]. The intra op complications encountered in emergency cesarean tend to more ofextendedincision,
Thin lower uterine segment, bladder advancement and hemorrhage. Cebeku L reported significant Intra op difficulties like fetal head impaction in almost one third of cesarean delivery and greater blood loss [9], similar to our study.

Vardhan et al[10] found that foetal distress was the commonest indication for emergency repeat caesarean section but in our study, previous LSCS was found to be most common indication for cesarean section. 
Our study correlates with DanielSet al [11] found that, In elective caesarean section group, previous caesarean section was the main reason for caesarean section accounting for $78 \%$, others being malpresentation $14.9 \%$, IUGR $3.9 \%$, CPD $1.3 \%$ and placenta preavia $1.3 \%$ which is similar to our study. In elective caesarean section group, previous caesarean section was the main reason for caesarean section accounting for $78 \%$, others being malpresentation $14.9 \%$, IUGR $3.9 \%$, CPD $1.3 \%$ and placenta preavia $1.3 \%$. This is comparable to other reported studies where repeat caesarean section was $30.7 \%$ and malpresentation $17.1 \%$ [12]. The increased incidence of repeat caesarean section is due to the absence of patients opting for vaginal birth after caesarean section. In emergency caesarean section group fetal distress was the main reason for caesarean section, accounting for $30.3 \%$. Others were $18 \%$ each for previous caesarean section and failed induction, $9 \%$ each for dystocia \&CPD, $4.5 \%$ each for malpresentation and twins, $3.4 \%$ for abruption, $1.1 \%$ each for placenta preavia, IUGR and caesarean delivery on maternal request. In a previously reported study the leading indication for emergency caesarean section was cephalopelvic disproportion (39.3\%), while antepartum hemorrhage and fetal distress followed in that order [13].

In our study of neonatal outcome in the elective group, $684(98.27 \%)$ were live births and only 12 (1.72\%) were perinatal deaths. While in the emergency group, there were $2242(88.93 \%)$ live births, 184 (7.29\%) perinatal deaths and $95(3.77 \%)$ still births. Sharma et al [14] found that total neonatal admissions were 23 in which 3 were in the vaginal delivery group, 7 were in the elective cesarean group and 13 were in the emergency cesarean group. In one casethere was scar rupture and in other case cesarean section was done for obstructed labour with severe PIH. In other studies neonatal death was seen in $0.66 \%$ and $0.61 \%$ cases respectively $[15,16]$

Anagha A et al[17] found that Perinatal morbidity was higher in cases of repeat caesarean delivery than in those who had a successful VBAC $(12.12 \%$ Vs 0 percent). Maternal complications were also higher in patients who had a repeat LSCS compared to those who had a successful VBAC (12.76\% Vs 2.74\%).From various recentstudies on the subject of birth after previous caesareandelivery, it would be safe to conclude that a trial for VBAC after a prior LSCS constitutes a safe form of obstetrical management[18].
George O Ugwu et al [19] concluded that most women who had one previous Cesarean delivery chose to undergo trial of VBAC, although only about half were considered suitable for VBAC. The maternal and fetal outcomes of trial of VBAC in selected women with one previous Cesarean delivery for non-recurrent indications were good. Obstetricians in this area should do more to allow VBAC in women with one previous Cesarean section for non recurrent indications, correlates with other studies[20,21]

Maternal and perinatal outcome of our study correlates to study done byAnupamaSuwalet al[22], they found that the overall complication rate is higher in emergency cesarean section than in elective cesarean Section, similar to our study.

\section{Conclusion}

The trend of cesarean section is increasing in most of the countries. Its incidence seems to be increasing in M.G.M Medical College and M.Y. Hospital, Indore (M.P) also. Complication rates are more common in Cesarean than in vaginal delivery but these complications are encountered more commonly in emergency than in elective CS, further studies are required for measures which are effective to decrease the incidence of cesarean section.

\section{Funding:Nil. Conflict of interest: Nil. Permission for IRB: Yes}

\section{References}

1. Cunningham FG, Leveno KJ, BLOOM SL et al wenstorm KD, editors. Williams Obstetrics. $22^{\text {nd }}$ ed. Newyork: McGraw-Hill Companies;2005.available on download.bioon.com

\section{Clark SL, Belfort MA, Dildy GA, Herbst} MA, Meyers JA, Hankins GD. Maternal death in the 21st century: causes, prevention, and relationship to cesarean delivery. Am J Obstet Gynecol. 2008 Jul;199(1):36.e1-5; discussion 91-2. e7-11. doi: 10.1016/j.ajog.2008.03.007. Epub 2008 May 2.

3. Elvedi-Gasparović V, Klepac-Pulanić T, Peter B. Maternal and fetal outcome in elective versus emergency caesarean section in a developing country. Coll Antropol. 2006 Mar;30(1):113-8.

4. National Vital Statistics Reports Volume 62, Number 1 June 28,2013 - nvsr62_01.pdf [Internet]. [cited 2013 
Dec

19].

Availablefrom:http://www.cdc.gov/nchs/data/nvsr/nvsr 62/nvsr62_01.pdf

5. Khawaja NP, Yousaf T, Tayyeb R. Analysis of caesarean delivery at a tertiary care hospital in Pakistan. J Obstet Gynaecol. 2004 Feb;24(2):139-41.

6. Belizán JM, Althabe F, Cafferata ML. Health consequences of the increasing caesarean section rates. Epidemiology. 2007 Jul;18(4):485-6.

7. Al Nuaim L, Soltan MH, Khashoggi T, Addar M, Chowdhury N, Adelusi B. Outcome in elective and emergency cesarean sections: A comparative study. Ann Saudi Med. 1996 Nov;16(6):645-9.

8. Kumar R. Prevention of maternal mortality: why success eludes us? Indian J Public Health. 2002 JanMar;46(1):3-7.

9. Cebeku L, Buchmann EJ. Complications associated with cesarean section in second stage of labor. Int $\mathbf{J}$ ObstetGynecol : 2006 Nov;95(2):110-4. Epub 2006 Aug 23.

10.Vardhan S, Behera RC, Sandhu GS, Singh A, Bandhu HC. Vaginal birth after caesarean delivery. J ObstetGynecol India 2006;56:320-3.

11.suja daniel1, manjushaviswanathanstudy of maternal outcome of emergency andElective caesarean section in a semi-ruralTertiary hospitalnational journal of medical researchvolume $4\lceil$ issue $1 \mid$ jan - mar 2014. Available on njmr.in

12. Najam R, Sharma R. Maternal and fetal outcomes in elective and emergency caesarean sections at a teaching hospital in North India. A retrospective study. Journal Of advanced researches in Biological Sciences. 5(3):59.

13. Nwobodo EI, Isah AY, Panti A. Elective caesarean section in a tertiary hospital in Sokoto, north western
Nigeria. Niger Med J. 2011 Oct;52(4):263-5. doi: 10.4103/0300-1652.93801.

14. Sharma A, Sharma U et al Maternal and Neonatal Outcome in Patients with History of Previous One Cesarean Section Indian Medical Gazette - MAY 2012.Available on medind.nic.in

15. Nahar K., Akhter L., Chowdhary S. B. - Outcome of pregnancy with history of previous cesarean section. The ORION Medical Journal.31: 588-590, Sep. 2008.

16.Chhabra S., Arora G. - Delivery in women with previous cesarean section. J Obstet Gynaecol India. 56(4): 304-307, 2006.

17.Anagha A. Jinturkaret al Study of Obstetric and Fetal Outcome of Post Caesarean Section Pregnancy at Tertiary Care International Journal of Recent Trends in Science And Technology, , Volume 10, Issue 3, 2014 pp 530-537.

18. RCOG Green top guideline No. 45. Birth after previous caesarean birth. Feb2007.Available on www.rcog.org.uk

19. George O Ugwu, ${ }^{1}$ Chukwuemeka A Iyoke Maternal and perinatal outcomes of delivery after a previous Cesarean section in Enugu, Southeast Nigeria: a prospective observational studyInt $\mathrm{J}$ Womens Health. 2014; 6: 301-305.

20. Tahseen S, Griffiths M. Vaginal birth after two caesarean sections (VBAC-2)-a systematic review with meta-analysis of success rate and adverse outcomes of VBAC-2 versus VBAC-1 and repeat (third) caesarean sections. BJOG. 2010 Jan;117(1):5-19. doi: 10.1111/j.1471-0528.2009.02351.x.

21. Ilesanmi AO, Odukogbe A, Olaleye DO. Vaginal delivery after one caesarean section in Nigerian women. J Obstet Gynaecol. 1997 Mar;17(2):139-42.

22. Suwal A, Shrivastava VR, Giri A. Maternal and fetal outcome in elective versus emergency cesarean section. JNMA J Nepal Med Assoc. 2013 OctDec;52(192):563-6.

\section{How to cite this article?}

Thakur V, Chiheriya H , Thakur A, Mourya S. Study of maternal and fetal outcome in elective and emergency caesarean section. Int J Med Res Rev 2015;3(11):1300-1305. doi: 10.17511/ijmrr.2015.i11.236. 